\title{
The impact of social adjustment policy on Syrian refugees
}

\author{
Hussein Salem Al-Srehan \\ Al Ain University \\ Abu Dhabi, \\ $U A E$ \\ alsrehanbussein@gmail.com, bussein.alsrehan@aau.ac.ae \\ ORCID 0000-0001-5464-5726
}

Abstract. This study aims to investigate the impact of social adjustment policy on Syrian refugees, whereas the study population is composed of all Syrian refugees in Jordan. The sample of refugees in different regions of Jordan was surveyed (1675 in total). In order to achieve the objective of the study, the social adjustment scale was constructed in the final form of 20 items. After confirming its validity and stability, it was applied to the sample. The results show that the impact of the social adjustment policy on Syrian refugees in Jordan depends on gender factors, duration of asylum, and the

Received: December, 2019 1st Revision: May, 2020

Accepted: August, 2020

DOI: place of residence, but does not depend significantly on the education level. Social adaptation more characterizes men, and there are significant differences between the level of social adaptation in Badia, as well as between urban residences and in rural ones.

Keywords: social adjustment policy, Syrian refugees, social adaptation, immigration.

JEL Classification: J15, J61, F01

\section{INTRODUCTION}

The Arab Spring revolutions became a milestone in recent history. Marches took place in various Arab countries to demand change, freedom, and rehabilitation (Beck \& Hüser, 2015). Confrontation methods varied as well as demands, especially in Syria which witnessed a bloody civil war. The only solution for many Syrian civilians became displacement and resorting to neighboring countries. Jordan is one of the most important countries that have embraced Syrian people as the number of Syrian refugees in Jordan reached 1.5 million according to the official statistics.

According to international conventions, refugee generally means "anyone who is forced to leave his country due to external aggression, occupation, or foreign domination as a result of ethnic, religious, or social reasons" (Stahnisch \& Russell, 2016; Yousaf, 2018). 
According to the group of researchers (Gadeberg et al., 2017), a refugee is a person who lives outside his or her country of habitual residence because of persecution as a result of religion, nationality, membership of a particular social group or political opinion and, because of that fear, he does not want to remain protected or return to that country for fear of being subjected to persecution, or murder and escaping from injustice.

Jones-Smith (2019) asserts that refugees are more likely than others to be affected by psychological stress. These stresses produce many symptoms such as: anxiety, conflict, and frustration, which in turn lead to severe psychological effects and very serious social effects. The most important of these outputs: physical, mental, and psychosomatic diseases, the negative impact on human achievement, and performance in general.

There is a close relationship between conflicts, internal or external one, and the mental health of an individual which is supposed to be supported through Security, Trust, Acceptance, Love, and Appreciation (Linehan, 2018). This is confirmed by Allen (2020) whose research on mental health and psychosocial adaptation for young refugees after migration confirms high prevalence of disorder, anxiety, and depression.

Some researchers attribute high anxiety and depression and the low level of social adaptation of a refugee to severe effects of wars and conflicts resulting in traumatic experiences experienced by individuals of all ages, since children, men, women, and the elderly alike are exposed to them at different stages of their lives (Khamis, 2017; Alshoubaki \& Zazzara, 2020). These experiences affect the level of individual adaptation to a new society.

Therefore, social adaptation plays an important role in modifying the relationship between the perception of stressful life events and psychopathological symptoms in general and the symptoms of depression in particular. Not only does it alleviate the impact of these pressures, but it may also have protective effects from these pressures through healing of mental disorders, thus contributing to personal growth of the individual (Terziev, 2017).

Social adaptation is a process that is inclusive and continuous, it helps individuals change their behavior to create a more harmonious relationship with the environment (Buchanan et al., 2018). This process also aims at satisfying psychological and social needs of the individual within the surrounding environment which requires the individual make continuous efforts to face these difficulties and solve them, and this is a form of normal human behavior to reach compatibility and adaptation (Fiske, 2018).

There are many factors that help individuals adapt to society. Some of these factors are related to the individuals themselves, others are related to family, school, peers, and the wider community. Moreover, individual characteristics such as age, physical health and pre-migration experiences also have impact on the level of individual adaptation (Lincoln et al., 2016). In addition, societal factors such as integration into a host community have been associated with positive outcomes of mental health and social adaptation among migrants and refugees (Fazel, 2018).

Since March 2011, refugees' waves of Syrian displacement forced migration of more than 4 million people from inside Syria. 1.5 million of them were forced to seek asylum in neighboring countries. As of May 2013, Jordan has been hosting 470,000 of Syrian refugees. This number increased in the first three months of 2013, when the conflict intensified and spread to major cities across Syria. Two-thirds of Syrian refugees in Jordan reside outside international camps and are scattered in urban and rural communities across the country, facing challenges with living expenses, access to basic services, adapting to the specific nature of Jordanian society, and dealing with severe psychological and social distress (Alshoubaki \& Zazzara, 2020). This study reveals the impact of social adjustment policy on Syrian refugees.

The Hashemite Kingdom of Jordan has embarked on adopting the policy that encourages the integration of Syrian refugees into Jordanian society and reduces the negative effects of asylum. This has aroused the curiosity of the researcher to conduct this study and reveal the effectiveness of this policy. 
Therefore this study analyzes the impact of social adjustment policy on Syrian refugees. Accordingly, the problem of the present study was determined by answering the following questions:

Question 1: To what extent does social adjustment policy affect Syrian refugees in Jordan?

Question 2: Are there statistically significant differences in the study sample estimates on the impact of social adjustment policy on Syrian refugees in Jordan due to the impact of gender, duration of asylum, educational level and the place of residence?

The present study seeks to achieve the following objectives:

1. To identify the impact of social adjustment policy on Syrian refugees in Jordan.

2. To disclose differences across the respondents on the extent to which social adjustment policy affects Syrian refugees in Jordan in terms of gender, duration of asylum, educational level and the place of residence.

3. To come up with a set of recommendations that would contribute to activating social adjustment policy on Syrian refugees in Jordan.

\section{Procedural definitions}

Social adjustment policy: Intended to organized and purposeful process to help the individual to abide by the ethics of the community and keep up with social standards and to interact with others to ensure a balance between the individual and the social framework in which he lives (Neely-Prado et al., 2019; Terziev, 2019). For the purpose of this study, adaptation policy are procedurally defined as the combination of efforts Jordan continuously provides to Syrian refugees to help them overcome the effects of asylum and contribute to their mental health and community integration.

Refugees: A refugee is defined as any person who has been forced to leave his or her home for fear of persecution and to be outside his homeland (Hasawi, 2008: 54), For the purpose of this research, a Syrian refugee is defined as a person living outside his country of habitual residence in the Syrian Arab Republic because of a well-founded fear of persecution because of religion, nationality, membership of a particular social group or political opinion, and cannot because of that fear.

\section{The study limits:}

This study contained the following limits:

- A sample of Syrian refugees in various governorates of the Kingdom for 2018.

- The measure of social adaptation built by the researcher and according to his observations and conclusions, so it is not possible to generalize the results of this study outside the objective framework of its tool.

\section{LITERATURE REVIEW}

The Arabic and foreign literature were surveyed, and studies related to the current study viewed in chronological order:

ALharbi (2017) conducted a study aimed at identifying the degree of psychological safety and selfefficacy among Syrian refugee students inside and outside the camps. The sample consisted of 600 Syrian refugee students at home and abroad camps in the second semester of the academic year 2014-2015. The Psychometric and Self-Efficiency Scale was implemented to answer study questions. The results indicated a low degree of psychological security for Syrian refugee students inside the camps but moderate outside the camps. The results also showed a low level of self-efficacy among Syrian refugee students inside and outside the camps. 
Li and Grineva (2016) conducted a study aimed at identifying the level of social adaptation among a sample of newcomers from refugee background in a high school in Newfoundland and Labrador. And to achieve this goal, the study data were collected through field observations, qualitative survey questionnaires of 15 new students, and interviews with 6 students from refugee background and 3 teachers. The results indicated that young refugees face difficulties in the level of social adjustment due to differences in educational systems and school cultures and thus suffer from social isolation and various practices in body language, dress code, and personal hygiene.

Basheti et al. (2015) sought to detect the prevalence of mental disorders experienced by Syrian refugees in Za'atari camp in Jordan. A sample of (73) refugees was selected, the results indicated that Syrian refugees suffer from difficult living conditions, which resulted in increased psychological pressure, in addition to the low level of health and psychological services. In Za'atari camp, people with psychiatric disorders suffer from psychological and social support, especially for those living in refugee camps.

Jabbar and Zaza (2014) aimed at detecting the level of psychological and social adjustment among the students of the higher basic stage of the Syrian refugees in Zaatari camp (Jordan). And to achieve this goal, a random sample of (382) male and female students was selected in Za'atari camp. The results showed that the level of social adjustment was moderate, and the study showed that there are statistically significant differences according to the gender, while no differences in the level of social adjustment according to the duration of stay.

Collins et al. (2017) conducted a study aimed at identifying the situation of Syrian refugees in Turkey, as well as to identify the most important impact of the Syrian conflict on humanitarian attitudes towards Syrian refugees in Turkey, the researcher used in this study descriptive analytical method. The study sample consisted of 1072 refugees from Syrian families who is living inside the camps in Turkey. The study found that the Turkish government is paying much attention to improving the living conditions of the refugees inside the camps. It also found that the refugees suffer from problems such as housing and difficult living conditions, in addition to the lack of some basic needs such as food, blankets and others.

The current study is distinguished from previous studies in its comprehensiveness in terms of the size of the sample as well as the place of its selection where the current study covered the northern governorates of the Hashemite Kingdom of Jordan. The study was not limited to Zaatari camp, which is making the study more comprehensive than previous studies.

Creating solutions to address the problems of social and economic adaptation of Syrian refugees in Jordan requires using the experience of adaptation of migrants in many other countries. Studies of the adaptation of forced migrants in the EU countries show a huge role in this process of the labor market and the independent placement of migrants, among whom there are a lot of refugees (Navickas et al., 2020). Researchers confirmed that the countries of EU have a tendency to convergence in regard to the share of self-employed migrants in employed persons from foreign countries. Were assumed that pressure of the labour market where a lack of labour force is obvious will prolong this trend. There are relatively large number of self-employed migrants in Eastern Europe. Their increase can be considered averagecompared to the EU. There is the study focuses on attitudes towards immigrants and the factors that contribute to dissimilarity. Among them, the most important were trust, fear of those migrants who are lower level of trust in national institutions, the difference in religion (Danaj et al., 2018). The stay of Syrian refugees in Jordan is largely due to the geographical proximity of this country to their homeland and the proximity of religion, way of life and customs. Studies of Mishchuk and Grishnova (2015) shows that a significant number of refugees inclined to migrate to countries with higher standards of living and opportunities. The study is devoted to the study of what factors migrants tend to choose a place of resettlement. The most significant factors of external migration found are health care needs, conditions for life extension, level of protection 
of human rights, insurance for the material component of life and higher standards of living (Mishchuk \& Grishnova, 2015).

\section{METHODOLOGY}

\subsection{Study approach}

The present study followed the descriptive analytical approach. The descriptive analytical approach refers to the quantitative research based on sociological review. SPSS Statistics software was used for statistical analysis of the collected data.

\subsection{Study population and sample}

The study population consisted of all Syrian refugees in the northern governorates of the Hashemite Kingdom of Jordan for the year 2018, and due to the lack of accurate statistics on the number of refugees in the northern governorates, the researcher selected a random sample consisting of (1675) refugees, and table (1) shows the distribution of the individuals of sample according to the study variables.

Table 1

Iterations and percentages according to study variables

\begin{tabular}{|l|l|c|c|}
\hline \multirow{3}{*}{ Gender } & \multicolumn{1}{|c|}{ Categories } & Iteration & Percentage \\
\hline \multirow{5}{*}{ Duration of asylum } & Male & 873 & 52.1 \\
\cline { 2 - 4 } & Female & 802 & 47.9 \\
\hline \multirow{5}{*}{ Educational level } & Less than two years & 755 & 45.1 \\
\cline { 2 - 4 } & More than two years & 920 & 54.9 \\
\cline { 2 - 4 } & Secondary level and below & 271 & 22.9 \\
\cline { 2 - 4 } & Diploma & 384 & 60.9 \\
\cline { 2 - 4 } & $\begin{array}{l}\text { Bachelor's degree and } \\
\text { above }\end{array}$ & 1020 & 27.5 \\
\hline & Badia & 460 & 25.6 \\
\cline { 2 - 4 } & Rural area & 429 & 46.9 \\
\cline { 2 - 4 } & City & 686 & 100.0 \\
\hline
\end{tabular}

Source: developed by the authors

\subsection{Study tool}

To achieve the objective of the study, reference was made to the theoretical literature and previous studies related to the subject of the study, such as (ALharbi, 2017) study and the guide of social adjustment scale that was built by (Jassi et al., 2020) and the views of arbitrators and specialists in psychological counseling and psychology. In light of this, a measure of social adaptation was developed for the study sample and the questionnaire consisted in its initial form of (20) items.

Validity of the study tools:

The validity of the study tool was verified in two ways:

1- The veracity of the arbitrators: The veracity of the tool was confirmed by presenting it to (6) arbitrators from the faculty members of the Jordanian universities. The researcher asked them to give their comments and opinions on the validity of these items and represent the purpose for which it was prepared, and the suitability of each item to the area in which it was placed, and add or delete any item they deem 
appropriate. After the restoration of the questionnaires, it was found that the arbitrators proposed to amend the language of items $(6,9,13,18)$ and the amendment was made as required.

2- Building validity: To extract the significance of construction validity for the scale, extracted the coefficients of the correlation of meaning of each item of the scale with the total score were performed. For this study, 45 refugees were randomly selected from the same population, but separate from the sample used for the main study. The correlation coefficient represents an indication of sincerity for each item in the form of a correlation between each item and the total score. In the same time, it indicates correlation between each item and its association with the field to which it belongs, and between each field and the total score. The correlation coefficients of items with the tool as a whole ranged between (0.92-0.59), and with the field (0.95-0.68) the table (2) shows that.

Table 2

The correlation coefficients between the items, the total score and the field to which they belong

\begin{tabular}{|c|c|c|c|}
\hline Item number & $\begin{array}{c}\text { The correlation } \\
\text { coefficient with the tool }\end{array}$ & Item number & $\begin{array}{c}\text { The correlation } \\
\text { coefficient with the tool }\end{array}$ \\
\hline 1 & $* * 0.82$ & 11 & $* * 0.90$ \\
\hline 2 & $* * 0.86$ & 12 & $* * 0.92$ \\
\hline 3 & $* * 0.88$ & 13 & $* * 0.90$ \\
\hline 4 & $* * 0.87$ & 14 & $* 0.79$ \\
\hline 5 & $* * 0.81$ & 15 & $* 0.91$ \\
\hline 6 & $* * 0.79$ & 16 & $* 0.87$ \\
\hline 7 & $* * 0.84$ & 17 & $* 0.86$ \\
\hline 8 & $* * 0.59$ & 18 & $* 0.89$ \\
\hline 19 & $* * 0.64$ & 20 & $* 0.81$ \\
\hline
\end{tabular}

3- * Statistically significant at the significance level (0.05).

4- $\quad$ * Statistically significant at the significance level (0.01).

Source: developed by the authors

It should be noted that all correlation coefficients were acceptable and statistically significant, therefore none of these items were deleted.

\subsection{Study tool stability}

To ensure the reliability of the study tool, the test-retest method was verified by applying the test and reapplied after two weeks to a group of 45 refugees outside the study sample. The Pearson correlation coefficient between their estimates also was calculated both times on the study instrument as a whole, the coefficient of stability was also calculated by the method of internal consistency according to the Kronbach alpha equation (0.84). and the coherence coefficient was calculated by the method of internal consistency according to the Kronbach Alpha equation (0.80). These values were considered appropriate for the purposes of this study.

\subsection{Study variables}

The present study included the following variables (Table 3): 
Description of independent variables

\begin{tabular}{|l|l|}
\hline \multirow{2}{*}{ Gender } & Male \\
\cline { 2 - 2 } & Female \\
\hline Duration of asylum & Less than two years \\
\cline { 2 - 2 } & Two years and more \\
\hline Educational level & Secondary level and below \\
\cline { 2 - 2 } & Diploma \\
\cline { 2 - 2 } & Bachelor's degree and above \\
\hline Residence & Badia \\
\cline { 2 - 2 } & Rural area \\
\cline { 2 - 2 } & City \\
\hline
\end{tabular}

Source: developed by the authors

The dependent variable in this study is the impact of social adjustment policy on Syrian refugees in Jordan.

\subsection{Study procedures on refugees}

To reach the results of the study, the researcher has done the following:

1. Determining the objective of the study to reveal the impact of social adjustment policy on Syrian refugees in Jordan.

2. Building the tool of study in the light of theoretical literature and previous relevant studies, in accordance with the scientific procedures followed in the construction of tools and the calculation of honesty and stability. Then make sure it is true or not.

3. Selecting the members of the sample and then interviewing them and explaining the purpose of the study to them.

4. Distributing the study tool to the study sample.

5. Filling the necessary data by the members of the study sample and then answer the items of the tool as they see with their point of view in all honesty and objectivity. After being informed them that their answers are confidential and will only be used for scientific research purposes.

6. Collecting data and then enter the data into the computer memory, then using the statistical program (SPSS) to analyze and extract the results, and then discuss and interpret and make recommendations and proposals.

\subsection{Statistical processing}

The following statistical analyzes were used to answer the study questions:

1. To answer the first question, the arithmetic averages were extracted for the items of the tool fields and the fields as a whole.

2. To answer the second question, a multi-impact quadrilateral analysis of gender, duration of asylum, educational level and place of residence was conducted.

3. For the purposes of interpreting the results and concluding the final results in this study, the Likert Ladder has been adopted by the correction tools of the study, giving each of itsitem one grade among its five grades (Strongly Agree, Agree, Neutral, Opposed, actively Opposes) and it is digitally represented (5, 4, $3,2,1)$ respectively, the following scale has been adopted for the purposes of analyzing the results: 
From 2.33 - 1.00 few.

From 3.67 - 2.34 medium.

From 5.00 - 3.68 large.

\section{RESULTS AND DISCUSSION}

The first question: What is the impact of social adjustment policy on Syrian refugees in Jordan?

To answer this question, we have extracted the arithmetic averages and standard deviations of the impact of social adjustment policy on Syrian refugees in Jordan. The table 4 illustrates this.

Table 4

Arithmetic averages and standard deviations of items of the impact of social adjustment policy on Syrian refugees in Jordan

\begin{tabular}{|c|c|c|c|c|c|}
\hline Rank & Number & Items & $\begin{array}{l}\text { Arithmetic } \\
\text { averages }\end{array}$ & $\begin{array}{l}\text { Standard } \\
\text { deviation }\end{array}$ & Level \\
\hline 1 & 3 & $\begin{array}{l}\text { Social adjustment policy secure the } \\
\text { integration of Syrian refugees with the local } \\
\text { community }\end{array}$ & 3.16 & 1.203 & middle-level \\
\hline 2 & 6 & $\begin{array}{l}\text { The community in Jordan accepts the idea of } \\
\text { the existence of Syrian refugees }\end{array}$ & 3.13 & 1.176 & middle-level \\
\hline 3 & 13 & $\begin{array}{l}\text { Social adjustment policy promote the media } \\
\text { to provide an appropriate picture of Syrian } \\
\text { refugees }\end{array}$ & 3.13 & 1.192 & middle-level \\
\hline 4 & 18 & $\begin{array}{l}\text { Social adjustment policy ensure that a } \\
\text { refugee feels desirable }\end{array}$ & 3.12 & 1.222 & middle-level \\
\hline 5 & 20 & $\begin{array}{l}\text { Social adjustment policy ensure that families } \\
\text { of Syrian refugees are reunited }\end{array}$ & 3.05 & 1.151 & middle-level \\
\hline 6 & 10 & $\begin{array}{l}\text { Social adjustment policy provide refugees } \\
\text { with the opportunity to raise their standard } \\
\text { of living }\end{array}$ & 3.05 & 1.227 & middle-level \\
\hline 7 & 1 & $\begin{array}{l}\text { Social adjustment policy provide an } \\
\text { opportunity for Syrian refugees to face the } \\
\text { traumatic experiences they have experienced }\end{array}$ & 3.02 & 1.168 & middle-level \\
\hline 8 & 17 & $\begin{array}{l}\text { Social adjustment policy promote Syrian } \\
\text { refugee talent }\end{array}$ & 2.93 & 1.189 & middle-level \\
\hline 9 & 2 & $\begin{array}{l}\text { Social adjustment policy provide qualified } \\
\text { professionals to identify the psychological } \\
\text { and social problems that experienced by the } \\
\text { Syrian refugee }\end{array}$ & 2.91 & 1.164 & middle-level \\
\hline 10 & 12 & $\begin{array}{l}\text { Social adjustment policy ensure that } \\
\text { legislation against violence against refugees } \\
\text { is limited }\end{array}$ & 2.89 & 1.275 & middle-level \\
\hline 11 & 14 & $\begin{array}{l}\text { Social adjustment policy encourage Syrian } \\
\text { refugees to attend school }\end{array}$ & 2.88 & 1.176 & middle-level \\
\hline 12 & 15 & $\begin{array}{l}\text { Social adjustment policy encourage refugees } \\
\text { to overcome loneliness }\end{array}$ & 2.86 & 1.182 & middle-level \\
\hline 13 & 4 & $\begin{array}{l}\text { Social adjustment policy provide specialized } \\
\text { centers for reporting abuse cases to Syrian } \\
\text { refugees }\end{array}$ & 2.79 & 1.022 & middle-level \\
\hline
\end{tabular}




\begin{tabular}{|c|c|l|c|c|c|}
\hline 14 & 5 & $\begin{array}{l}\text { Social adjustment policy are keen to } \\
\text { promote cooperation between members of } \\
\text { the local community and Syrian refugees }\end{array}$ & 2.75 & 1.311 & middle-level \\
\hline 15 & 11 & $\begin{array}{l}\text { Social adjustment policy provide } \\
\text { psychological support and care for Syrian } \\
\text { refugees }\end{array}$ & 2.71 & 1.155 & middle-level \\
\hline 16 & 9 & $\begin{array}{l}\text { Social adjustment policy provide refugees } \\
\text { with the opportunity to raise their standard } \\
\text { of living }\end{array}$ & 2.70 & 1.060 & middle-level \\
\hline 17 & 19 & $\begin{array}{l}\text { Social adjustment policy encourage visits } \\
\text { between refugees on the one hand and the } \\
\text { community on the other }\end{array}$ & 2.70 & 1.278 & middle-level \\
\hline 18 & 16 & $\begin{array}{l}\text { Social adjustment policy guide refugees to } \\
\text { follow up with social workers }\end{array}$ & 2.64 & 1.227 & middle-level \\
\hline 19 & 20 & $\begin{array}{l}\text { Social adjustment policy encourage visits } \\
\text { between refugees and the community }\end{array}$ & 2.61 & 1.201 & middle-level \\
\hline 20 & 7 & $\begin{array}{l}\text { Social adjustment policy contribute to } \\
\text { familiarizing Syrian refugees with the most } \\
\text { prevalent values in Jordanian society }\end{array}$ & 2.59 & 1.187 & middle-level \\
\hline
\end{tabular}

Source: developed by the authors

Table (4) shows that the arithmetic averages ranged between (3.16-2.59), where item (3), which states that "Social adjustment policy are keen to integrate the Syrian refugee with the local community" ranked first with an average of 3.16. Item (7), which reads, "Social adjustment policy contribute to the definition of the Syrian refugee with the most prominent values prevailing in the Jordanian society", with an average of 2.59. The mean of the field as a whole has reached (2.90).

The second question: Are there statistically significant differences at the level of indication $(a=0.05)$ in the study sample estimates on the impact of social adjustment policy on Syrian refugees in Jordan due to the impact of gender, duration of asylum, educational level and place of residence?

To answer this question, we have extracted the arithmetic averages and standard deviations of the extent of the impact of social adjustment policy on Syrian refugees in Jordan according to variables of the impact of gender, duration of asylum, educational level and place of residence. The table (5) shows this. 
Table 5

Arithmetic averages and standard deviations of the responses of the study sample of the impact of social adjustment policy on Syrian refugees in Jordan according to variables of gender, duration of asylum, educational level and place of residence

\begin{tabular}{|c|c|c|c|}
\hline Characteristics of refugees & Group of respondents & Indicators & Adaptation policy \\
\hline \multirow[t]{4}{*}{ Gender } & \multirow[t]{2}{*}{ Male } & $\mathrm{A}$ & 3.75 \\
\hline & & $\mathrm{D}$ & 0.60 \\
\hline & \multirow[t]{2}{*}{ Female } & $\mathrm{A}$ & 3.72 \\
\hline & & $\mathrm{D}$ & 0.58 \\
\hline \multirow[t]{4}{*}{ Duration of asylum } & \multirow[t]{2}{*}{ Less than two years } & $\mathrm{A}$ & 3.75 \\
\hline & & $\mathrm{D}$ & 0.61 \\
\hline & \multirow[t]{2}{*}{ More than two years } & A & 3.87 \\
\hline & & $\mathrm{D}$ & 0.54 \\
\hline \multirow[t]{6}{*}{ Educational level } & \multirow{2}{*}{$\begin{array}{c}\text { Secondary level and } \\
\text { below }\end{array}$} & $\mathrm{A}$ & 3.80 \\
\hline & & $\mathrm{D}$ & 0.56 \\
\hline & \multirow[t]{2}{*}{ Diploma } & $\mathrm{A}$ & 3.70 \\
\hline & & $\mathrm{D}$ & 0.61 \\
\hline & \multirow{2}{*}{$\begin{array}{l}\text { Bachelor's degree and } \\
\text { above }\end{array}$} & $\mathrm{A}$ & 3.72 \\
\hline & & $\mathrm{D}$ & 0.59 \\
\hline \multirow[t]{6}{*}{ Residence } & \multirow[t]{2}{*}{ Badia } & $\mathrm{A}$ & 3.79 \\
\hline & & $\mathrm{D}$ & 0.61 \\
\hline & \multirow[t]{2}{*}{ Rural area } & A & 3.59 \\
\hline & & $\mathrm{D}$ & 0.63 \\
\hline & \multirow[t]{2}{*}{ City } & $\mathrm{A}$ & 3.78 \\
\hline & & $\mathrm{D}$ & 0.54 \\
\hline
\end{tabular}

$A=$ Arithmetic averages; $D=$ standard deviations

Source: developed by the authors

Table (5) shows an apparent variation in the arithmetic averages and standard deviations of the respondents' responses on the extent to which social adjustment policy affect Syrian refugees in Jordan due to different categories of variables, gender, duration of social asylum, educational level and place of residence. To illustrate the significance of statistical differences between the arithmetic averages, the analysis of the multiple quadratic variance of the tool as a whole was used as Table (6).

Table 6

Analysis of the quadruple contrast of the impact of gender, duration of asylum, educational level and place of residence on the impact of social adjustment policy on Syrian refugees in Jordan

\begin{tabular}{|l|c|c|c|c|c|}
\hline Contrast Source & Total squares & $\begin{array}{c}\text { Degrees of } \\
\text { freedom }\end{array}$ & Average squares & Values & $\begin{array}{c}\text { Statistical } \\
\text { significance }\end{array}$ \\
\hline Gender & 3.180 & 1 & 3.180 & 10.053 & 0.002 \\
\hline $\begin{array}{l}\text { Duration as } \\
\text { asylum }\end{array}$ & 45.167 & 1 & 45.167 & 142.807 & 0.000 \\
\hline $\begin{array}{l}\text { Educational } \\
\text { level }\end{array}$ & 0.470 & 2 & 0.235 & 0.743 & 0.476 \\
\hline $\begin{array}{l}\text { Place of } \\
\text { residence }\end{array}$ & 16.601 & 2 & 8.300 & 26.244 & 0.000 \\
\hline The error & 527.550 & 1668 & 0.316 & & \\
\hline Total & 586.390 & 1674 & & & \\
\hline
\end{tabular}

Source: developed by the authors 
Table (6) shows the following:

- There are statistically significant differences $(0.05 \geq a)$ attributed to the effect of gender, and the differences were in favor of males.

- There are statistically significant differences $(0.05 \geq a)$ attribute the duration of the asylum and the differences were in favor of two years and more.

- There are no statistically significant differences $(0.05 \geq a)$ due to the effect of educational level.

- There are statistically significant differences $(0.05 \geq a)$ attributed to the effect of the place of residence to show the statistically significant marital differences between the arithmetic averages, the dimensional comparisons were used as shown in Table (7).

Table 7

Dimensional comparisons of the impact of place of residence on the impact of social adjustment policy on Syrian refugees in Jordan

\begin{tabular}{|l|c|c|c|c|c|}
\hline & & $\begin{array}{c}\text { Arithmetic } \\
\text { average }\end{array}$ & Badia & Rural area & City \\
\hline $\begin{array}{l}\text { Adaptation } \\
\text { policy }\end{array}$ & Badia & 3.79 & & & \\
\hline & Rural area & 3.79 & $* 0.21$ & & \\
\hline & City & 3.68 & 0.02 & $* 0.19$ & \\
\hline
\end{tabular}

Level of significance $(0.05 \geq a)$.

Source: developed by the authors

Table (7) shows the following:

- There are statistically significant differences $(a=0.05)$ between the category of residence (Badia) on the one hand and each of the place of residence (village, city) on the other hand, and the differences were in favor of each Badia and city.

Results show that the level of impact of social adjustment policy on Syrian refugees in Jordan depends on gender factors, duration of asylum and place of residence, but does not depend on educational level. The previous result may reflect a clear deficiency in social adjustment policy, perhaps due to the large numbers of refugees, which limits the effectiveness of social adjustment policy as there are no accurate statistics neither on refugee's circumstances, nor the nature of pressures they face, no effective coping policy can in any way be established without knowing the background brought by the refugee and grew up in, on one side, as well as sources of pressure on the other, and whether it is internal because he has forced to leave his country, or external as a result of his inability to adapt in new Communities.

There are statistically significant differences $(0.05 \geq a)$ attributed to the effect of gender, and the differences were in favor of males, the differences were in favor of two years and more, and the Place of residence, The category of the place of residence (Badia) on the one hand and both categories of (village, city) on the other. The difference comes in favor of each city and the previous result may be attributed to the fact that males are facing the pressures of life more than females because the residence of females are mostly in the home of the family in contrast to males, those who go out to work for the requirements of life, which makes them more contact with the local community and thus more. Ability to adapt to the new community as well as with regard to the variable of residence. It is noted that the differences came category of place of residence (Badia) on the one hand and both categories of place of residence (village, city) on the other. The differences were in favor of each Badia and City, probably because most of the Syrian refugee communities were in the eastern areas of Jordan (or Badia) or in cities and villages, but a few of them of them were in the villages, therefore they had less social adjustment in the villages compared to the Badia or 
urban areas. This finding is partly in line with the findings of (Li \& Grineva, 2016) which showed that the level of social adaptation of the Syrian refugee is low due to different traditions and social values prevailing according to the variable of residence. The Syrian refugee population is affected by the place of residence where the level of adjustment outside the camps was higher than inside the refugee camps according to (ALharbi, 2017) study.

\section{CONCLUSIONS}

In light of the above results it was found that the general level of social adaptation of Syrian refugees in Jordan depends on gender factors, duration of asylum and place of residence, but does not depend on educational level. It was found that social adaptation is more pronounced in men, and also significant differences between level of social adaptation in Badia, as well as in urban residences and in rural ones. The differences were in favor of each Badia and City residences.

The researcher recommends the following: 1) To intensify social adjustment policy through the provision of more psychologists to help refugees adapt to new communities. 2) To undertake activities that promote the promotion of common values between the Syrian refugee and the local community in order to promoting social adjustment. 3) Conducting studies similar to the current study to identify the causes of low social adjustment among Syrian refugees in Jordan.

This study has theoretical and practical significance as follows:

Theoretical importance: Increased emphasis on the duration of the effectiveness of social adaptation policy as they play a significant role in reducing the negative effects of asylum and providing an opportunity for refugees to join in new societies and enrich the theoretical side of research and studies through the present theoretical framework and data collection tool and thus open the way for other studies.

Practical importance: This study is an extension of the previous studies and complementary to them. The previous studies focused on identifying social adjustment policy for different segments of individuals, while this study is concerned with detecting the impact of social adjustment policy on Syrian refugees in Jordan, thus this study can contribute to the detection of The strengths and weaknesses of the adjustment policy adopted by the Hashemite Kingdom of Jordan in particular for Syrian refugees.

\section{REFERENCES}

ALharbi, B.H. (2017). Psychological Security and Self-Efficacy among Syrian Refugee Students inside and outside the Camps. Journal of International Education Research, 13(2), 59-68.

Allen, C. (2020). Psychological distress in refugee children. Pan American Health Organization.

Alshoubaki, H., \& Zazzara, L. (2020). The fragility in the land of refugees: Jordan and irrepressible phenomenon of refugee camps. Journal of International Studies, 13(1), 123-142. https://doi.org/10.14254/2071-8330.2020/13-1/8

Basheti, I.A., Qunaibi, E.A., \& Malas, R. (2015). Psychological Impact of Life as Syrian Camp in Jordan. Tropical Journal of Refugees: A Pilot Study Pharmaceutical Research, 14(9), 1695-1701.

Beck, M., \& Hüser, S. (2015). Jordan and the 'Arab spring': no challenge, no change?. Middle East Critique, 24(1), 8397. https://doi.org/10.1080/19436149.2014.996996

Buchanan, Z.E., Abu-Rayya, H.M., Kashima, E., Paxton, S.J., \& Sam, D.L. (2018). Perceived discrimination, language proficiencies, and adaptation: comparisons between refugee and non-refugee immigrant youth in Australia. International journal of intercultural relations, 63, 105-112. https://doi.org/10.1016/j.ijintrel.2017.10.006

Collins, D.R., Jobanputra, K., Frost, T., Muhammed, S., Ward, A., Shafei, A.A., ... \& Heneghan, C. (2017). Cardiovascular disease risk and prevention amongst Syrian refugees: mixed methods study of Médecins Sans Frontièresprogramme in Jordan. Conflict and health, 11(1), 14. https://doi.org/10.1186/s13031-017-0115-z 
Danaj, A., Lazányi, K., \& Bilan, Y. (2018). Perceptions and implications of immigration in France-economic, social, political and cultural perspectives. Economics \& Sociology, 11(3), 226-247. https://doi.org/10.14254/2071789X.2018/11-3/14

Fazel, M. (2018). Psychological and psychosocial interventions for refugee children resettled in high-income countries. Epidemiology and psychiatric sciences, 27(2), 117-123. https://doi.org/10.1017/S2045796017000695

Fiske, S.T. (2018). Social beings: Core motives in social psychology. John Wiley \& Sons.

Gadeberg, A.K., Montgomery, E., Frederiksen, H.W., \& Norredam, M. (2017). Assessing trauma and mental health in refugee children and youth: a systematic review of validated screening and measurement tools. European Journal of Public Health, 27(3), 439-446. https://doi.org/10.1093/eurpub/ckx034

Hasawi, N. (2008).Refugee Rights Between Legitimacy and Palestinian-Israeli Negotiations. Beirut: Zaytouna Center for Studies. Jabbar, S.A., \& Zaza, H.I. (2014). Impact of conflict in Syria on Syrian children at the Zaatari refugee camp in Jordan. Early child development and care, 184(9-10), 1507-1530. https://doi.org/10.1080/03004430.2014.916074

Jassi, A., Lenhard, F., Krebs, G., Gumpert, M., Jolstedt, M., Andrén, P., ... \& Mataix-Cols, D. (2020). The work and social adjustment scale, youth and parent versions: psychometric evaluation of a brief measure of functional impairment in young people. Child Psychiatry \& Human Development, 51, 453-460. https://doi.org/10.1007/s10578-020-00956-z

Jones-Smith, E. (2019). Theories of counseling and psychotherapy: An integrative approach. SAGE Publications, Incorporated.

Khamis, V. (2017). Psychological distress of parents in conflict areas: the mediating role of war atrocities, normative stressors and family resources. Journal of Mental Health, 26(2), 104-110. https://doi.org/10.3109/09638237.2016.1139072

Li, X., \& Grineva, M. (2016). Academic and Social Adjustment of High School Refugee Youth in Newfoundland. TESL Canada Journal, 34(1), 51-71.

Lincoln, A.K., Lazarevic, V., White, M.T., \& Ellis, B.H. (2016). The impact of acculturation style and acculturative hassles on the mental health of Somali adolescent refugees. Journal of Immigrant and Minority Health, 18(4), 771 778. https://doi.org/10.1007/s10903-015-0232-y

Linehan, M.M. (2018). Cognitive-behavioral treatment of borderline personality disorder. Guilford Publications.

Mishchuk, H., \& Grishnova, O. (2015). Empirical study of the comfort of living and working environment-Ukraine and Europe: comparative assessment. Journal of International Studies, 8(1), 37-80. https://doi.org/10.14254/2071$8330.2015 \% 2 \mathrm{~F} 8-1 \% 2 \mathrm{~F} 6$

Navickas, V., Grmanová, E., \& Gajda, W. (2020). Self-employment of foreigners as an innovative solution on the labor market in the European Union. Business: Theory and Practice, 21(1), 178-183. https://doi.org/10.3846/btp.2020.11727

Neely-Prado, A., Navarrete, G., \& Huepe, D. (2019). Socio-affective and cognitive predictors of social adaptation in vulnerable contexts. PloS one, 14(6), e0218236. https://doi.org/10.1371/journal.pone.0218236

Stahnisch, F.W., \& Russell, G. (2016). New perspectives on forced migration in the history of twentieth-century neuroscience. Journal of the History of the Neurosciences, 25(3), 219-226. https://doi.org/10.1080/0964704X.2015.1121694

Terziev, V. (2017). Studying different aspects of social adaptation. International Health, 9(6), 1352-1361. https://dx.doi.org/10.2139/ssrn.3143184

Terziev, V. (2019). Conceptual framework of social adaptation. Proceedings of INTCESS 2019- 6th International Conference on Education and Social Sciences, 4-6 February, 2019, At Dubai (pp. 494-503).

Yousaf, F.N. (2018). Forced migration, human trafficking, and human security. Current Sociology, 66(2), $209-225$. https://doi.org/10.1177\%2F0011392117736309 